\title{
EFFECTS OF DIETARY CANISTEL (POUTERIA CAMPECHIANA) FRUIT MEAL ON GROWTH PERFORMANCE AND CARCASS PARAMETERS OF BROILER CHICKEN
}

\author{
Atapattu NSBM*, Sanjeewani KGS and Senaratna D \\ Department of Animal Science, Faculty of Agriculture, University of Ruhuna, Mapalana, Kamburupitiya
}

Accepted: 06 February 2014

\begin{abstract}
Pouteria campechiana (Canistel) is an under-utilized tree fruit grown naturally in many tropical and sub-tropical regions. Objective of this study was to determine the effects of dietary Canistel fruit meal (CFM) on growth and carcass parameters of 3-6 week old broiler chicken. Ninety broiler chicks in 30 pens, were fed one of the five isoproteonic broiler finisher diets containing either 0 (control), 5, 10, 15 and 20\% of CFM from day 21 to 42 . The dietary level of CFM had no significant (P>0.05) effects on final live weight on day 42, weight gain from day 21 -42, water intake, carcass weight and dressing percentage. However, feed conversion ratio (FCR) of the birds given control diet was significantly lower than that of the birds given diets with CFM. The weights of the visceral organs and the length of the small intestine in relation to empty carcass weight were not significantly different among treatments. The abdominal fat pad weight of the birds given $10 \%$ CFM was significantly lower than that of the birds given diet without CFM. It was concluded that the up to $20 \%$ CFM can be included in broiler finisher diets without any adverse effects on health, mortality, growth and carcass parameters.
\end{abstract}

Key words: Alternative, Broiler, Canistel, Feed, Pouteria

\section{INTRODUCTION}

The energy requirement of commercial poultry feeds are mainly supplied with cereals such as maize, wheat, barley and their by products. Increasing demand for cereals by human food sector has limited the cereals available for the feeding of mono-gastric animals such as poultry. From recent years, maize; the principle energy source of poultry feeds is increasingly been used for biofuel production as well. Due mainly to above reasons, the price of poultry feed and consequently the price of poultry products increased sharply during recent years (Aho 2007). Scanes (2008) reported that increased feed ingredient prices have severe negative impacts on livestock producers and the consumer, particularly those in developing countries. In these circumstances, screening, evaluation and the utilization of alternative or non conventional feed ingredients for poultry have been identified as a key research priority (Sheldon 1998 2000).

Preston (1992) suggested evaluating the feasibility of cereal-free poultry diets based on ma- terials such as sugarcane, cassava roots, sweet potato tubers, and banana and plantain fruits for intensive poultry feeding. A range of materials such as distillers dried grain with soluble (Martinez et al 2007), dried tomato seeds (Persia et al. 2003), sugar syrup (John 2008), finger millet (Reddy et al. 2008), yam peel meal (Akinmutini and Onen, 2008), mango kennel meal (Diarra and Usman, 2008) and sorghum (Reddy et al. 2008) have been studied as alternative energy feed ingredients for poultry feeding, at varying success.

Canistel, (Pouteria campechiana), is an underutilized, multi-purpose fruit crop belonged to family sapotaceae, and is grown naturally in many areas of the tropical and sub-tropical regions. Canistel is commercially grown in many Central American countries and some States of USA. Botanical aspects of Canistel have been described by Morton (1987; 1992) and Pushpakumara (2007). One tree yields $136-250 \mathrm{~kg} /$ fruit/year (http:www//ocuc.iwmi.org/files/ Resources /Factsheet/Pouteria.pdf). The immature mesocarp contains a high level of sticky latex. The dark yellow colour ripen mesocarp

*Corresponding author: nsbm@ansci.ruh.ac.lk 
is very sweet. Canistel is a nutritious fruit containing $1.7 \%$ of $\mathrm{CP}, 37 \%$ carbohydrates, $3.7 \mathrm{mg}$ niacin and $0.32 \mathrm{mg}$ carotein $/ 100 \mathrm{~g}$ of fresh weight. Even though the fruit can be used for human consumption, in Sri Lanka, Canistel (Pouteria campechiana) is hardly used for human consumption; but goes wasted. The objective of this study was to investigate the effects of Canistel fruit meal on growth performance and carcass parameters of 3-6 weeks old broiler chicken.

\section{MATERIALS AND METHODS}

Preparation of CFM: Mature (but unripen) Canistel fruits were obtained from local home gardens. The outer waxy peel was removed by using a knife. Then fruits were cut into several pieces and seeds were removed. Starchy mesocarp was cut into thin slices (1-2mm) and sticky latex was wiped out with papers. Canistel slices were then immersed in boiling water for 8 minutes and oven dried at $80{ }^{\circ} \mathrm{C}$ for three days. Dried Canistel slices were ground to get CFM. The mean diameter of the CFM pieces was $1 \mathrm{~mm}$. Samples of CFM were analyzed for crude protein and crude fibre (AOAC 1995). The gross energy value of CFM was determined using adobe bomb calorimeter.

Chick assay-Birds and Management: Day old male broiler chicks (Cobb) were obtained from a local hatchery. Birds were brooded in an electrically heated floor brooder for 12 days. Until day 20, chicks were given a commercial broiler starter feed ad libitum. On day 20, ninety chicks were allocated into thirty floor pens so that between pen live weight variation was minimum. Each pen had a feeder and a drinker. Paddy husk was the litter material. From day 21 to 42 , birds were fed one of the five experimental diets ad libitum. Pen-wise daily feed and water intakes were determined. Birds were weighed weekly. On day 42, one randomly selected bird from each pen was slaughtered. Carcass parameters such as the weight of the liver, heart, gizzard, pancreas, empty digestive tract, abdominal fat pad, empty carcass, and the length of the digestive tract were determined.
Experimental diets: Five experimental diets containing $0,5,10,15$ and 20\% CFM were formulated. The diet containing $0 \% \mathrm{CFM}$ (the control diet; C) met the nutrient levels as set out by NRC (1994). In formulating the diets containing CFM, the metabolizable energy value of CFM was considered as $0.75 \mathrm{x}$ determined gross energy value of CFM. The CP content of CFM was considered as $3.3 \%$ and thus all five diets were isoproteionic. The levels of other nutrients such as lysine, methionine, calcium and available phosphorus of the CFM were not considered in formulating diets containing CFM. The ingredient composition and the calculated nutrient compositions of the experimental diets are shown in Table 1.

\section{Statistical analysis}

Data were analyzed using GLM procedure of SAS (1985). In the analysis of growth performance data, pen means served as replicates. In carcass parameter analysis, individual bird served as replicates. Effects were considered significant at $\mathrm{P}<0.05$. Significantly different means were compared by using Duncan multiple range test.

\section{RESULTS AND DISCUSSION}

Preparation of CFM: Ripened Canistel fruits have soft-sweet flesh with low amount of latex. However, harvesting and the hot water treatment of ripen fruit were cumbersome. Therefore, in this experiment, un-ripped, but well matured (yellow colour) fruits were used to get CFM. Drying and subsequent grinding of wellmatured, but un-ripened fruits having deep yellow colour flesh resulted in a dark brown colour grits which were easier to incorporate into diets. However, the main problem of unripened fruits was the presence of sticky latex. Cutting of Canistel fruits into thin slices, subsequent wiping with papers and hot water treatment removed the latex to a great extent. During the four weeks of storage, CFM or the diets containing CFM showed no signs of rancidity, fungal growth or discolouration.

CFM contained $89 \%$ dry matter and $3.3 \% \mathrm{CP}$. The CP content of CFM was lower than some 
of the cereals such as oats $(11.6 \%)$, polished rice $(8.7 \%)$, rye $(12.1 \%)$ and sorghum $(8.8 \%)$ (NRC 1994) and seed meals of some fruits such as avocado (7.2\%), jac (11.2\%) and mango $(7.8 \%)$ (Samarasinghe 2007) used in poultry feeds. Canistel is a poor source of $1 \mathrm{y}-$ sine $(0.08 \%)$, methionine $(0.01 \%)$ and tryptophan $(0.028 \%)$ (Morton 1987). Therefore, protein value of CFM seems to be low.

Table 1. The ingredient and the nutrient compositions of the experimental diets

\begin{tabular}{|c|c|c|c|c|c|}
\hline \multirow[t]{2}{*}{$\overline{\text { Ingredient }}$} & \multicolumn{5}{|c|}{ Dietary Canistel level (\%) } \\
\hline & 0 & 5 & 10 & 15 & 20 \\
\hline Fish meal & 5.0 & 5.0 & 5.0 & 5.0 & 5.0 \\
\hline Canistel fruit meal & 0 & 5.0 & 10.0 & 15.0 & 20.0 \\
\hline Rice bran & 20.0 & 20.0 & 20.0 & 20.0 & 20.0 \\
\hline Yellow maize meal & 37.5 & 32.5 & 26.0 & 19.0 & 21.0 \\
\hline Coconut oil Meal & 7.0 & 6.0 & 6.0 & 7.0 & 3.0 \\
\hline Coconut oil & 7.05 & 6.7 & 6.35 & 6.9 & 4.05 \\
\hline Soybean meal & 13.0 & 18.0 & 16.0 & 17.7 & 20.2 \\
\hline Gingerly oil meal & 8.0 & 4.0 & 8.0 & 6.0 & 4.2 \\
\hline L-Lysine & 0.08 & 0.08 & 0.08 & 0.08 & 0.08 \\
\hline Shell powder & 1.3 & 1.3 & 1.2 & 1.3 & 1.1 \\
\hline Dicalcium phosphate & 0.75 & 0.8 & 0.75 & 0.8 & 0.6 \\
\hline DL-Methionine & 0.6 & 0.6 & 0.6 & 0.6 & 0.25 \\
\hline Salt & 0.25 & 0.25 & 0.25 & 0.25 & 0.25 \\
\hline $\begin{array}{l}\text { Vitamin mineral mix- } \\
\text { ture } \\
\text { Nutrient composition }\end{array}$ & 0.25 & 0.25 & 0.25 & 0.25 & 0.25 \\
\hline${ }^{1} \mathrm{CP}$ (Calculated) & 20 & 20 & 20 & 20 & 20 \\
\hline (Analyzed) & 19.6 & 19.8 & 19.6 & 19.8 & 20 \\
\hline${ }^{2} \mathrm{ME}(\mathrm{MJ} / \mathrm{kg})$ & 13.38 & 13.38 & 13.38 & 13.38 & 13.38 \\
\hline $\mathrm{Ca}$ & 0.9 & & & & \\
\hline $\begin{array}{l}\text { Non phytate phospho- } \\
\text { rus }\end{array}$ & 0.35 & & & & \\
\hline Lysine & 1.1 & & & & \\
\hline Crude fibre & 5 & & & & \\
\hline
\end{tabular}

1. Assuming CFM contains $3.3 \% \mathrm{CP}$

2. Assuming the $\mathrm{ME}$ of $\mathrm{CFM}=\mathrm{GE} \times 0.75$
CFM contained as low as $3.9 \% \mathrm{CF}$. The $\mathrm{CF}$ content of CFM was more or less similar to cereals such as finger millet (Eleusine caracana) $(3.9 \%)$ but much lowers than that cereal by products such as rice bran (Samarasignghe 2007). The ME values of CFM in poultry were not available in literature. The gross energy value of CFM was as high as $17.5 \mathrm{MJ} / \mathrm{kg}$. The GE value of CFM is comparable with that of the feed ingredients such as some wheat varieties $(17.5 \mathrm{MJ} / \mathrm{Kg})$ (Saki 2005) but lower than that of feed ingre-

$\mathrm{MJ} / \mathrm{Kg}$ ), rice bran $(19.4 \mathrm{MJ} / \mathrm{Kg})$, rice $(18.32$ $\mathrm{MJ} / \mathrm{Kg}$ ) (Robles and Ewans, 1982) and coconut poonac $(19 \mathrm{MJ} / \mathrm{Kg}$ ) (McDonalds et al., 1995).

The flesh of Canistel is very sweet and has as high as 25 Brix value (Crane et al., 2001). Morton (1992) reported that Canistel contains $38 \mathrm{~g}$ of carbohydrates $/ 100 \mathrm{~g}$ of fresh weight. High gross energy value with low fibre content of CFM suggests that it may be an alternative energy feed ingredient for poultry. However, further research is needed to determine ME value of CFM in poultry.

Suggesting that up to $20 \%$ dietary CFM has no adverse effects on broilers. No mortalities, visible health or welfare problems were reported across all treatment throughout the experiment. Effects of dietary CFM on growth performance and carcass parameters of broiler chicken are shown in Table 2.

In general, dietary CFM increased the feed intake. Feed intake of the birds fed $15 \%$ dietary CFM was numerically higher than that of control birds while birds fed other CFM levels significantly increased the feed intake compared to the control group. It has been well established that birds eat to satisfy their energy requirement and thus increase the intake when the energy content of the diet decreased (Kamran et al. 2008, Leeson et al. 1996). In ration formulation, the ME value of CFM was considered as GE x 0.75 . However, there may 
be a possibility that the actual ME level of CFM is lower than that value and thus may be the reason for higher feed intake of the birds given diets with CFM. Had the CFM not been palatable, the intakes of diets containing CFM might not have been high, even the diets contained lower energy level. This suggests that CFM is palatable to poultry and can be included into broiler diets up to 20, without any adverse effects on feed intake.

Water intake values of the birds given diets with CFM were significantly higher than that of the birds fed control diet. Water intake has found to be highly correlated with feed intake. Higher water intakes of the birds given CFM containing diets compared to control birds may be due to the higher feed intake of the birds in former groups. Non significant water to feed ratios among the five treatments strengthens this argument.

Final live weight on day 42 and live weight gain from day 21-42 of the broilers fed different dietary CFM levels were not statistically different from each other. Feed conversion

Table 2: feed and water intake, live weight and carcass parameters of broilers fed on diets containing five levels of Canistel fruit meal from 21 - 42 days

\begin{tabular}{|c|c|c|c|c|c|c|}
\hline \multirow[t]{2}{*}{ Parameter } & \multirow[b]{2}{*}{0} & \multicolumn{3}{|c|}{ Dietary Canistel fruit meal level (\%) } & \multirow[b]{2}{*}{20} & \multirow[t]{2}{*}{ ANOVA } \\
\hline & & 5 & 10 & 15 & & \\
\hline $\begin{array}{l}\text { Feed intake }(\mathrm{g} / \mathrm{b} / \mathrm{d}) \\
\text { Water intake }(\mathrm{ml} / \mathrm{b} / \mathrm{d})\end{array}$ & $\begin{array}{l}113.6 \pm 1.3^{c} \\
363 \pm 19.9^{c}\end{array}$ & $\begin{array}{l}132 \pm 9.9^{\mathrm{a}} \\
422 \pm 9^{\mathrm{a}}\end{array}$ & $\begin{array}{l}125.8 \pm 7.9^{\mathrm{ba}} \\
391 \pm 12.3^{\mathrm{b}}\end{array}$ & $\begin{array}{l}119.1 \pm 10.5^{\mathrm{bc}} \\
402 \pm 26.6^{\mathrm{ba}}\end{array}$ & $\begin{array}{l}128.7 \pm 7.2^{\mathrm{ba}} \\
391.9 \pm 25.1^{\mathrm{b}}\end{array}$ & $\begin{array}{l}* \\
* *\end{array}$ \\
\hline $\begin{array}{l}\text { Water:feed } \\
\text { Live weight on }\end{array}$ & $3.20 \pm 0.063$ & $3.19 \pm 0.28$ & $3.12 \pm 0.19$ & $3.37 \pm 0.33$ & $3.05 \pm 0.13$ & NS \\
\hline $21 \mathrm{~d}$ & $933 \pm 25.9$ & $923 \pm 11.3$ & $928.3 \pm 19.6$ & $926.1 \pm 12$ & $915.6 \pm 8$ & NS \\
\hline $28 \mathrm{~d}$ & $1200 \pm 51.9$ & $1263 \pm 43.5$ & $1274 \pm 59.5$ & $1212 \pm 81.3$ & $1193 \pm 79$ & NS \\
\hline $35 \mathrm{~d}$ & $1814 \pm 69^{\text {ba }}$ & $1861 \pm 63^{\mathrm{a}}$ & $1821 \pm 98^{\text {ba }}$ & $1748 \pm 71.8^{\mathrm{b}}$ & $1714 \pm 119^{b}$ & $*$ \\
\hline $42 \mathrm{~d}$ & $2123 \pm 117$ & $2090 \pm 157$ & $2094 \pm 123$ & $1948 \pm 19.9$ & $2009 \pm 125$ & NS \\
\hline \multicolumn{7}{|l|}{ Weight gain $(\mathrm{g})$} \\
\hline 21 to 28 & $266.6 \pm 43.7$ & $339.9 \pm 46.7$ & $345.2 \pm 43.8$ & $286.1 \pm 78.9$ & $277.2 \pm 79$ & NS \\
\hline 28 to 35 & $614.4 \pm 52.2$ & $597.7 \pm 78.9$ & $547.5 \pm 64.9$ & $535.5 \pm 98.3$ & $521.6 \pm 64$ & NS \\
\hline 35 to 42 & $308.3 \pm 79.7$ & $228.8 \pm 123$ & $272.7 \pm 117$ & $200.5 \pm 62$ & $294.9 \pm 104$ & NS \\
\hline 21 to 42 & $1189 \pm 105$ & $1166 \pm 165$ & $1165 \pm 122$ & $1022 \pm 23.9$ & $1093 \pm 130$ & NS \\
\hline Feed conversion ratio & $2.01 \pm 0.26^{\mathrm{b}}$ & $2.40 \pm 0.2^{\mathrm{a}}$ & $2.28 \pm 0.09^{\mathrm{a}}$ & $2.44 \pm 0.01^{\mathrm{a}}$ & $2.49 \pm 0.08^{\mathrm{a}}$ & $*$ \\
\hline \multicolumn{7}{|l|}{${ }^{1}$ Carcass parameters } \\
\hline Heart & $0.85 \pm 0.11$ & $0.78 \pm 0.12$ & $0.77 \pm 0.07$ & $0.7 \pm 0.12$ & $0.81 \pm 0.16$ & NS \\
\hline Gizzard & $2.35 \pm 0.4$ & $2.41 \pm 0.3$ & $2.07 \pm 0.21$ & $2.3 \pm 0.23$ & $2.4 \pm 0.26$ & NS \\
\hline Crop & $0.68 \pm 0.15$ & $0.57 \pm 0.09$ & $0.59 \pm 0.08$ & $0.7 \pm 0.18$ & $0.6 \pm 0.18$ & NS \\
\hline Liver & $4.48 \pm 0.87$ & $3.98 \pm 0.55$ & $4.14 \pm 0.53$ & $4.1 \pm 0.4$ & $4.4 \pm 0.36$ & NS \\
\hline Pancreas & $0.412 \pm 0.09$ & $0.40 \pm 0.07$ & $0.35 \pm 0.03$ & $0.35 \pm 0.06$ & $1.8 \pm 0.04$ & NS \\
\hline Intestine & $4.24 \pm 0.46$ & $3.75 \pm 0.37$ & $3.7 \pm 0.41$ & $3.5 \pm 1.0$ & $4.1 \pm 0.58$ & NS \\
\hline Abdominalfat & $2.27 \pm 0.79^{\mathrm{ba}}$ & $2.63 \pm 0.65^{\mathrm{a}}$ & $1.1 \pm 0.26^{\mathrm{c}}$ & $1.4 \pm 0.49^{\mathrm{bc}}$ & $1.8 \pm 0.35^{\mathrm{c}}$ & $* *$ \\
\hline
\end{tabular}

1. As a $\%$ of empty carcass

$\mathrm{NS} ; \mathrm{P}>0.05$

$* ; \mathrm{P}<0.05$

**; $\mathrm{P}<0.01$

Means within a raw bearing a same superscripts are not significantly different 
ratio of the birds fed diets without CFM was significantly better than that of the birds fed diets with CFM. Among the four dietary CFM levels, $10 \%$ dietary CFM gave the closest FCR to that of the control birds.

Absence of any negative effects of dietary CFM on live weights on day 42 , weight gain from day 21-42 and feed intake suggest that CFM could be included up to $20 \%$ in broiler finisher diets. However, comparison of FCRs suggests that birds fed CFM maintained a comparable growth rate and achieved similar final live weight as control group at the expense of more feed. As discussed earlier, the actual energy levels of the diets containing CFM could be lower than that the control diet. Several studies (Plavnik et al. 1997; Nahashon et al. 2005) have also shown a concomitant increase in feed intake and FCR when low energy diets are fed to poultry. It is hypothesized that had the diets were isocaloric (formulated taking the actual $\mathrm{ME}$ value of CFM into account) the FCR of the birds given CFM would have been comparable with that of the control birds.

None of the internal organ weights were significantly affected by the dietary CFM levels. Presence of some anti-proteolytic substances has found to cause pancreatic hypertrophy (Gallinger et al. 2003)). In this experiment, inclusion of CFM had no effect on the weight on the pancreas and thus the presence of antiproteiolytic substances may not be a serious problem of CFM. Another important finding of the experiment was the lower abdominal fat percentage found in birds fed diets containing $10 \%$ and $15 \%$ of dietary CFM, compared to control birds and birds and birds fed 5\% dietary CFM. Lower abdominal fat contents for goslin (Min et al. 2007) and broilers (Nahashon, 2005) fed diets containing low energy levels than those fed high energy diets have been reported. It is hypothesized that birds fed diets with CFM had lower excess energy to be deposited as fat due to their higher energy cost of feeding, compared to control birds.

\section{CONCLUSION}

Inclusion of Canistel (Pouteria campechiana) fruit meal in broiler finisher diets increased the feed intake and feed conversion ratio. Up to $20 \%$ Canistel fruit meal had no negative effects on growth performance or carcass parameters. Hence this under-utilized fruit can be included up $20 \%$ in broiler finisher diets.

\section{ACKNOWLEDGEMENT}

Technical support of Mr. PK Lal and MMK Premakumara is highly acknowledged

\section{REFERENCES}

Aho P 2007 Impact on the world poultry industry of the global shift to biofuels. Poult Sci. 86: 2291-2294.

Akinmutimi AH and Onen GE 2008 The response of broiler finisher birds fed graded levels of yam peel meal in place of maize-based diets. Poult Sci. 7 (5): 474-479.

AOAC (Association of official analytical chemists) 1995. Official method of analysis. $16^{\text {th }}$ edition. Arlington, Virginia, USA.

Crane JH, Belardi CF, Campbell CW and Regalado R 2001 Evaluation of "ORO" and "TROMPO" Canistel (Pouteria campechiana) at the university of Florida Tropical Education and Research Centre, Homesterad. Proc. Fla.State Hort.Soc. 114: 3-4.

Diarra SS and Usman BA 2008 Growth performance and some blood variables of broiler chickens fed raw or boiled mango kennel meal. Poult Sci. 7 (4): 315-318.

Gallinger CI, Suarez DM and Irazusia S 2003 Effects of rice bran inclusion on performance and bone mineralization in broiler chicks. J. Appl Poult Res. 13: 183-190.

John PJK 2008 Sugar syrup: the new energy feed for poultry. Worlds Poult Sci. 24(2):12-13.

Kamran Z, Sarwar M, Nisa M, Nadeem MA, Mahmood S, Babar ME and Ahmed S 2008 Effect of Low-Protein Diets Having Constant Energy-to-Protein Ratio on Performance and Carcass Characteristics of Broiler Chickens from One to Thirty-Five Days of Age. Poult Sci 87: 468-474. 
Leeson S, Caston L, Summers D 1996. Broiler response to energy or energy and protein dilution in the finisher diet. Poult Sci. 75: 522-528.

Martinez C-Amezcua, Parsons CM, Singh V, Srinivasan R and Murthy GS 2007. Nutritional characteristics of corn distillers dried grains with solubles as affected by the amounts of grains versus solubles and different processing techniques. Poult Sci 86: 2624-2630.

McDonalds P, Edwards RA, Greenhalgh, Morgan CA, 1995 In: animal nutrition. Fifth eds. Addison_Wesley, Essex, UK.

Min YN, Hou SS, Gao Y, Huang W and Liu FZ 2007 Effect of Dietary Crude Protein and Energy on Gosling Growth Performance and Carcass Trait. Poult Sci. 86: 661-664.

Morton JF 1987 Fruits in warm climates. Creative Resources Inc, Wintervilla, N.C., pp. 402405.

Morton JF 1992 Pouteria campechiana (Kunth Baehni. In: Verheij E W M and Coronel R E (eds). Plant Resources of South East Asia. No. 2. Edible Fruits and Nuts. PROCEA Foundation, Bogor, Indonesia, pp. 59 $-60$.

Nahashon SN, Adefope IN, Amenyenu A and Wright D 2005 Effects of Dietary Metabolizable Energy and Crude Protein Concentrations on Growth Performance and Carcass Characteristics of French Guinea Broilers. Poult Sci. 84:337-34484: 337344.

NRC 1994. Nutrient Requirements of Poultry, Ninth ed. National Academy Press, Washington, DC, USA.

Persia MA, Parsons CM, Schang IM and Azcona J 2003 Nutritional evaluation of dried tomato seeds. Poult Sci. 82: 141-146.

Plavnik WE, Sklan D, Bartov I and Hurwitz S 1997 The Response of Broiler Chickens and Turkey Poults to Dietary Energy Supplied Either by Fat or Carbohydrates. Poult Sci. 1997 76: 1000-1005.

Preston TR 1992. Alternative non-cereal diets for poultry. Livestock research for rural development 4(3) http://www.lrrd.org/lrrd4/3/ preston.htm, Last accessed on $3^{\text {rd }}$ June 2011.

Pushpakumara DKNG 2007 Chapter 16: LAVULU. Pouteria campechiana (Kunth)
Baehni In: In: Pushpakumara D K N G , Gunasena H P M and Singh V P 2007 (eds) Underutilized fruit trees in Sri Lanka. World Agroforestry Centre, South Asia Office, New Delhi, India. pp. 426436.

Reddy KV, Malathi V, Reddy BSV, Pratap Kumar KS, Umakantha B Jayanaik 2008 Effects of finger millet and sorghum replacing corn in presence of soy oil/fish oil and enzymes on performance of broilers. Int $\mathbf{J}$ Poul Sci. 8: 560-564.

Robles A and Ewan RC 1982 Utilization of energy of rice and rice bran by young pigs. $\mathbf{J}$ Anim Sci. 55: 572-577.

Saki AA 2005 Metabolizable energy and viscosity in response to cold and tropical cereals area in leghorn pullets. Int J Poult Sci. 4:13.

Samarasinghe K 2007 Feeds and feed formulations for poultry in Sri Lanka. DCL Printers, Dehiwala, Sri Lanka.

SAS Institute 1985. SAS User Guide. SAS Inc, Cary NC.

Scanes CG 2008. Contribution of poultry to life and economic development in the developing world. Poult Sci. 86: 2289-2290.

Sheldon BL 1998 Poultry and poultry products as resources for human health and food in the $21^{\text {st }}$ century. Proc. $6^{\text {th }}$ Asian pacific Poult Congress WPSA, Nagoya, Japan, pp 1-8.

Sheldon BL 2000 Research and development in 2000: Directions and priorities for the world's poultry science community. Poult Sci. 79: 147-158. 